\title{
Climate change adaptability of the agriculture sector in Yogyakarta, Indonesia
}

\author{
Endah Saptutyningsih ${ }^{1,{ }^{*}}$, Diah Setyawati Dewanti ${ }^{1}$ \\ ${ }^{1}$ Faculty of Economics and Business, Universitas Muhammadiyah Yogyakarta, Indonesia
}

\begin{abstract}
Climate change has a negative impact on the agricultural sector in Yogyakarta, Indonesia, especially the farms, which are highly vulnerable to climate-related disasters such as flood and drought, as well as pest attacks that may cause production failure. This study aims to build a model of climate change adaptability for farmers in Yogyakarta. This study is qualitative in nature by using data from Focus Group Discussion (FGD) involving the community members at the district level. Each of the 12 districts in the area sent two representations of farmer assistants. Data reliability and validity was ensured through triangulation; then examined by using content analysis. The adaptability models for climate change are presented in two scenarios; the first is caused by drought/flooding and the second is by pest attack. From the data, it could be concluded that farmers' mitigations consist of structural and non-structural approach. The construction of dam as part of the water management is the main structural mitigation undertaking. Learning the weather, the climate and other disaster causes were the main non-structural mitigation undertaking. Moreover, learning was not only from classes and practices, but also via technology transfer using free website sources to enrich farmers' knowledge in handling pest attack.
\end{abstract}

\section{Introduction}

Climate change has impacted many sectors in Special Region of Yogyakarya (henceforth Yogyakarta) including the agriculture sector. Agricultural land mapping using Geographic Information Systems (GIS) showed that the impact of climate change on agricultural land in Yogyakarta is mostly related to pests and diseases [1]. Climate change is projected to have severe consequences among the vulnerable agricultural populations [2] . Based on the firstyear mapping results [1], Yogyakarta may continue to experience impacts relating to pests, diseases, drought and flood. From the previous study, an economic valuation was subsequently carried out using a Contingent Valuation Method. The results showed that farmers in regions affected by climate change were mostly willing to pay a certain amount of money to adapt to climate change. Adaptation is an effective strategy to minimize the impacts and improve climate change resilience [3]. The agricultural sector must adapt by equipping farmers with relevant capacity in dealing with climate change. This can be optimised by giving them access to information, physical and financial resources [4].

\footnotetext{
*Corresponding author: endahsaptuty@umy.ac.id
} 
Based on the previous study found that the farmers who experienced the effects of climate change were willing to participate in the adaptation. It revealed that the willingness was influenced by household's assets, social capital, the forms of mitigation, and the geographical locations. The regression model also included climate change indicators i.e. annual rainfall and temperature. The results indicated that and literacy level of the household head, and the size of household have a positive and significant effect on the WTP to adapt to climate change. Household's assets affected the WTP differently as land size was positively and significantly associated with WTP but land tenure was not. Social capital i.e. trusts, the number of relatives living outside the village and the community involvement had a positive and significant influence on WTP. Climate-related risk to the respondents' farms also influences the WTP. The higher the risk, the greater the WTP. Rising temperature also had a positive and significant effect on the WTP adaptation to climate change [1]. These findings have indicated the need for policy scenarios to adapt to and mitigate the impacts of climate change in the agricultural sector. Therefore, the current study aims to determine the right policy scenarios for adapting the climate change impact on agriculture.

Land conservation has been used as an adaptation tool for climate change [5]. It can also be a strategy for farmers to deal with climate change threats in developing countries [6]; such as in the Nile Basin in Ethiopia, where more than 30 percent of farmers adopted land conservation measures to deal with the long-term impact of changes in temperature and rainfall. Applying strategic agricultural management approached can mitigate this kind of shocks [7]. Due to lack of technology [8], Ghana applied the following climate change coping strategies: mixed planting, drought resistant crops or varieties, soil erosion management, planting and regeneration of the crops and so on, all of which required social capital [9]. Smallholder farmers in Busia County modestly adapted to climate change by utilizing financial/economic resources despite their lack of in knowledge/information [10]. In other words, low political and economic capital subsequently restrict the ability to plan, schedule, promote and enforce adaptation measures. The adaptation depends on the availability of financial capital [11]. It is also important to avoid strategies that are too costly and complicated [12]. In extreme weather related events such as Hurricane Mitch, the Honduras Trust, as a norm in society, households helped the mitigation too [13] in the form of voluntary works. In the absence of government support in Vietnam, households assisted in the maintenance of sea dykes after a disaster [14].

Understanding the complementary factors for soil conservation in the face of climate change will therefore help in the design and implementation of sound conservation practices. Research has identified a strong relationship between climate change and soil conservation. For example, the effect of annual average rainfall on the adoption of rock terraces varies by agroecological type [15]. Their findings indicate arid regions were willing to invest more compared to areas with high rainfall. Other strategies are more agricultural-related, such as the use of drought-resistant varieties, changing planting dates, water management and irrigation, tree planting and soil conservation practices [16] In Indonesia, there is the plenty of evidence of research on strategy in the climate change adaptability. Therefore, this study aims to develop the adaptability model to the climate change for farmers in Yogyakarta, Indonesia. 


\section{Research Method}

\subsection{Study site}

This study uses primary data with unit-level analysis at the area level representing individual farmers who grow crops in the area. Because this study uses advisory conselors (BPP) representing farmers in various sub-districts in the Kulonprogo district, therefore, this study divides based on the division of locations or regions into two groups, namely companion groups located in North-East and West-Central. The selection of regions follows the mapping in the previous research, which were the areas impacted by floods, pests and diseases.

\subsection{Interview and FGD design}

We conducted a focus group discussion with two representatives of farmer assistants as key informants of each sub-district. They were invited to the focus group discussion (FGD) for two days on early October, 2019. There are twelve (12) sub-districts, so the number of key informants of 24 people. The FGD distribution is based on location clusters close to the gathering point that were in the North-East and West-South regions. The key informants (KI) for FGDs were divided into two groups based on the locations. FGDs are conducted to the Agricultural Assistance Agency (BPP) at the sub-district level. Twelve BPP representatives were selected to be involved in the FGD.

We used cluster random sampling that is identified by selecting the unit of analysis based on the area or division of the region in Kulonprogo Regency [17]. We were chosen randomly, because we only made appointments representing locations per district. Since Kulonprogo Regency has tens of thousands of farmers, to represent the various problems of these farmers, researchers chose one of the extension agents to represent KI's. KI's chosen based on the extension agents who actively assist farmers in the sub district cluster.

To obtain the integrated and continuous data, information and data collection in the compilation of climate change impacts scenarios, we also divided the FGD implementation groups based on cluster areas, namely: 1) BPP Lendah, Panjatan, Temon Groups; 2) BPP Kokap, Pengasih, Wates Groups; 3) BPP Kalibawang, Sentolo, Samigaluh Groups; 4) BPP Nanggulan, Galur, Gilimulyo Kelompok. The division of this group is based on the results of the first year, namely the calculation results from the WTP and also the results of field observations carried out before the FGD. Some grouping criteria are as follows: 1) Based on the type of location cluster or areas that are close to each other; 2) Based on case impacts during field observations; and 3) Based on input or ideas from the Kulonprogo Regency agriculture office, DI Yogyakarta Province. Instruments in the data collection process are structured interview guidelines based on the results of the first year of research.

\subsection{Data analysis}

We employed a QUAL method to determine the right policy scenarios for adapting the climate change impact on agriculture. The method did not have a rigid rule in determining the number of samples [18]. However, the determination of samples in the QUAL method is based on the saturation information method of KI [19, 20] Saturation is carried out when the researcher can collect complete information data and no longer find the updated data or information expected during the FGD. If in its implementation we have 
carried out the FGD more than three times but still gets updated information, then the FGD and indepth interview will still be carried out for the sake of collecting complete data [21].

The interview as a preliminary assessment was also conducted by the research team to the Kulonprogo Regency agriculture office to find out the suitability of the selected key informants. Data collection methods on QUAL are carried out using focus group discussions and non-participatory observation. QUAL data verification is done using the triangulation method in carrying out validity and reliability. Triangulation is done by multichecking from various sources, namely through differences in time of data retrieval, location and person. Validation and reliability in this research phase were carried out through a single FGD with a non-participation observation method.

The analytical tool used to process and analyse qualitative data is to use Atlas.ti version 8.0 which is carried out using the following steps:

1) Transcript of in-depth interview and FGD results in the form of Microsoft Word files;

2) Determine the code;

3) Determine the quote;

4) Content analysis.

\section{Result and Discussion}

\subsection{Assesment Analysis}

Yogyakarta Special Region Province has 5 regencies/cities, one of which is Kulonprogo Regency. Kulonprogo Regency is located on the westernmost side with a border area with Purworejo Regency, Central Java Province (on the West side); Sleman and Bantul Regencies, DI Yogyakarta Province (on the East side); Magelang Regency, Central Java Province (on the North side) and Indian Ocean (on the South Side). This study chose Kulonprogo district, where Kulonprogo district has the most dominant agricultural sector compared to the four other districts / cities. Kulonprogo Regency has a varied topography with altitudes between 0 - 1000 meters above sea level, with the following divisions:

North: is a plateau or hills with altitudes between 500 - 1000 meters above sea level. This northern area is divided into Girimulyo, Kokap, Kalibawang and Samigaluh districts. This area is designated as a conservation area and has a vulnerability to landslides.

Central Area: a hilly area with a height of between $100=500$ meters above sea level. This area is a transition from the lowlands and hills so that some areas are used for agriculture on certain types of plants. The Central Region includes Nanggulan, Sentolo, Pengasih and a part of Lendah sub-districts.

Southern Area: is a low area with a height of 0-100 meters above sea level. This area is an area with flood prone areas. Due to better water flow compared to other regions, the southern area is known as an agricultural area. The southern area includes Temon, Wates, Panjatan, Galur and a part of Lendah. This area is a coastal area along $24.9 \mathrm{~km}$. 


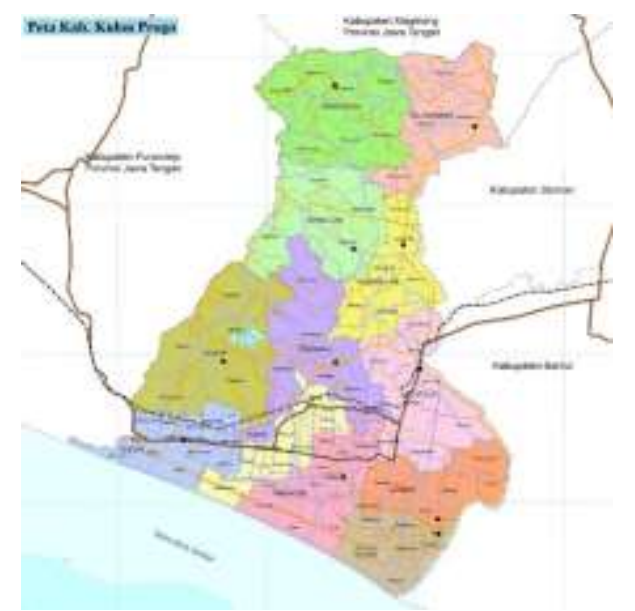

Fig. 1. Kulonprogo district

During 2015 in Kulonprogo Regency, the average rainfall per month was $164 \mathrm{~mm}$ and rainy days were 8 days per month. The highest average rainfall occurred in December 2015 amounted to $394 \mathrm{~mm}$ with a number of rainy days 17 days per month. Districts that have the highest average rainfall per month in 2015 are in Kalibawang District of $220 \mathrm{~mm}$ with 8 days of rainy days per month. Raw water sources in Kulonprogo Regency include 7 (seven) springs, Sermo Reservoir, and Progo River. The springs that have been managed by the PDAM include the Clereng, Mudal, Grembul, Upas Cave, and Progo River springs. In Kokap Subdistrict, springs are managed in a self-managed manner by the Subdistrict and Village, which are then channeled gravity by piping systems. Kulonprogo Regency, which is located between Menoreh Hill and the Indian Ocean, is crossed by the Progo River in the east and Bogowonto River and Glagah River in the west and center. The existence of a river with water that flows throughout the year in the Kulonprogo Regency area helps in maintaining the surface water conditions. The existence of the Sermo Reservoir in the Kokap Subdistrict is supported by the existence of an irrigation network that spreads almost in all sub-districts, demonstrating the seriousness of the Kulonprogo Regency Government to increase agricultural and fisheries production in the Kulonprogo Regency area.

Agriculture in Kulonprogo Regency represents DI Yogyakarta Province, covering horticultural food crops, forestry plantations, livestock and marine fisheries. From the, the GRDP (Gross Regional Domestic Product) of the Kulonprogo Regency is dominated by the Agriculture, Forestry and Fisheries sectors. From 2016 to 2018, the agriculture sector led the acceptance of the Kulonprogo Regency GRDP. Rice and secondary crops are commodities that dominate the results of planting in the agricultural sector. The potential agricultural crops in Kulonprogo include rice, corn and peanuts [22]. The population of forest products, especially timber, including teak, rosewood, mahogany and acacia is found because it has a high economic value.

Based on the value of GRDP, the agricultural sector dominates gross domestic production for input to other sectors. Therefore, infrastructure and physical development in the irrigation management system are very important.

\subsection{The grouping of farmer assistants}

Key Informants in this study were farmers' assistants who were divided into 12 subdistricts in Kulonprogo Regency. Each sub-district is represented by two assistants with experience 
in assisting at least 10 years. However, almost all assistants must have been moved to various districts in Kulonprogo.

"... from 1987 ... all of us on average have moved to move between sub-districts in the Kulonprogo district, but some people have also moved to other districts" (Male, Lendah, June 20, 2019).

Farmer companion placement in the location is based on several characteristics, namely based on domicile and overlay. Placement based on domicile is given to assisting farmers in the southern area or lower slope area, where the agricultural land is paddy field. Whereas the placement of overlays is based on groups in mountainous or small areas. However, in Kokap sub-district, the placement is based on hamlet domicile or cluster. That is, one companion can assist 30 farmers in 1 hamlet location.

"There are overlay groups and there are domicile groups. Domicile is one hamlet, one hamlet one group and there is another one for example, there is land here but the owner from far away can also be one group" (Male, Wates, June 20, 2019)

"If for paddy fields it is usually an expanse but if for a kind of agricultural environment the group might be if my place is yes, I'm in the mountains, on average the domicile of the mas is rarely spread, but if for the lower areas it is the average expanse" (Men, Lendah, June 20, 2019)

The Agriculture Sector in the Department of Agriculture includes the fisheries and marine components, but the characteristics of the agricultural assistant or farmer assistant are only devoted to the assistance of farmers cultivating food crops and forest plants. Several cases of fisheries on farmland, including the responsibility of a farmer companion in their respective regions. Therefore, the average farmer companion can assist farmers in 1 village consisting of 150 farmers and agricultural fisheries.

"If in Wates the 150s are included in the fisheries farmer groups, the problem is that fisheries now stand alone" (Male, Wates, 20 June 2019)

"Kokap is about 96 farmer groups, if it can be added with forest farmer groups, maybe the number can be more, because there are forest farmer groups too, potential in the mountains" (Male, Kokap, June 20, 2019)

\subsection{The knowledge of climate change}

To know the ability of adaptation in the agricultural sector, businessmen must understand the meaning of the problems faced by farmers and farmer assistants. Climate change is a natural problem that must be faced and handled by each farmer to maintain or even increase the amount of production. Therefore, this study will identify the notion of climate change from various perspectives of farmer assistants compared to the understanding in several theories.

Farmer assistants have the understanding of climate change in the background of causes and effects of natural phenomena due to human behavior without elaborating on the process of climate change (see Figure 2). For farmer assistants, climate change is described as a prolonged season and a change in pest genetic factors. A prolonged season can lead to vulnerability in the agricultural sector, especially in decreasing the amount of production in agricultural products. The prolonged season not only highlights cases of drought but also cases of prolonged rain causing floods. To identify the knowledge of farmer assistants, we ask "Do you understand about climate change and the impact on agriculture?"

"Understood. Some drought had occurred in Kulonprogo arising from prolonged drought, some rice fields were cracked and could not get 
water, there were no irrigation channels, there were also those who only relied on rainwater, there were also water that could be used by vacuuming use diesel for irrigation but is constrained by the additional costs that must be incurred to rent diesel and hoses to deliver water and also calculated profit and loss. For land that is already dry and does not receive water supply, it will usually be used as animal feed "(Male, Kalibawang, 21 June 2019)

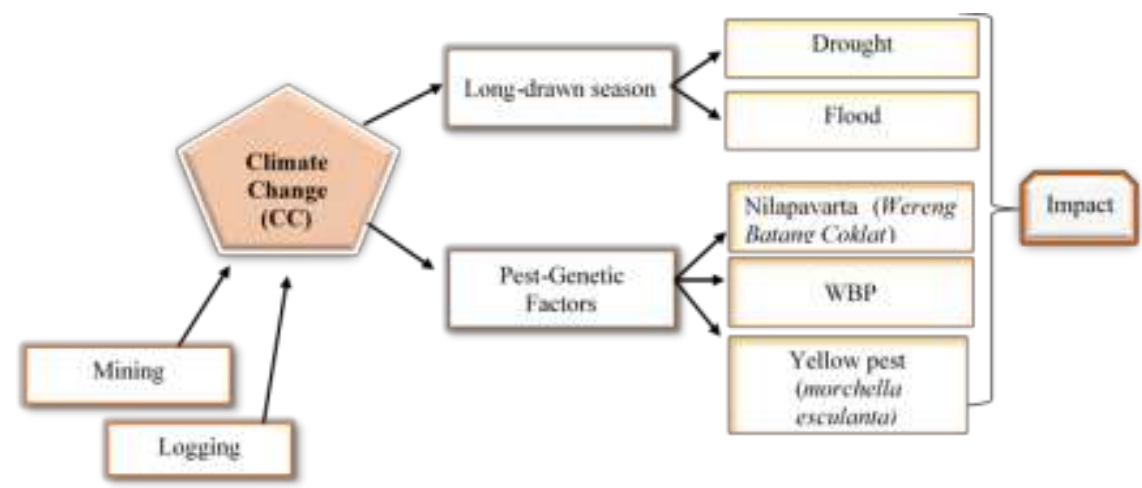

Fig. 2. The meaning of Climate Change on behalf of farmer' commission

Key informants state that climate change is caused by mining and logging so that water debit is reduced massively. Or flooding during prolonged rain due to the absence of trees that can store water. Climate change is considered as a result or impact of environmental damage that can harm farmers. Another description of climate change by farmer assistants, is explaining the development of pest genetics which makes it more difficult to increase production factors in the agricultural sector. Some pests that develop attack in the Kulonprogo district are brown planthopper (wereng batang coklat) and woro kuning mushroom types [23]. Brown planthopper began to develop after a prolonged drought in a few years ago. Woro kuning mushroom also appears after a prolonged rainy season and this type of pest attacks crops and rice.

Farmer assistants try to minimize the risk of pests in various ways due to Kulonprogo regency has a different climate between districts, one of which is to adapt the types of plants from the climate in certain areas. In Samigaluh Subdistrict, the area has many cliff characteristics so that sunlight is not widely available, therefore, the farmer assistant provides direction for growing coffee, tea and or cloves.

"In Samigaluh, it's the same because it's close to the mountains too. If in the area the cliffs are many cliffs. For plants need sunlight so that it inhibits plant growth but is less than optimal. For other crops, there are coffee, tea, cloves can also be planted in the fields ... "(Male, Samigaluh, June 21, 2019)

\subsection{Farmers Adaptive Capacity Process in Kulonprogo, Yogyakarta}

The process of adaptive capacity is the ability of an individual, community group, organization, state and or other actors to adapt to the impacts that occur now and in the future due to global changes [24]. Most people develop their level of knowledge and expertise in the process of implementing adaptive capacity. An efficient adaptation process 
carried out with Local Adaptive Capacity (LAC) where the level of adaptation must be significant with the socio-economic characteristics of each actor, in this case farmers [25].

Adaptation Capacity for farmers through a farmer companion is obtained by two kinds of things namely structural mitigation and non-structural mitigation (Figure 5). Structural mitigation is the reduction of the impact of disaster risk by means of infrastructure development. Some adaptive capacity programs carried out in the face of climate change, implemented with the construction of rain-fed reservoirs, in collaboration with local governments and PT. Pertamina.

"There is no irrigation in Samigaluh sub-district, so the irrigation is only from springs, so that during the dry season, it often lacks water even for bathing and drinking. There used to be many springs but now they are increasingly disappearing so there is a lack of water, maybe the behavior of the people of the day also affected the existence of the drought itself. In Samigaluh, a reservoir has been created in collaboration with PT. Pertamina is used to collect rain water and later it will be used to irrigate rice fields and land around Samigaluh. Another thing that we have tried to anticipate drought is by planting palm trees that are believed to hold a lot of water. Another objective of the funding of the palm tree is also to restore the spring sources that have long been lost ... "(Male, Samigaluh, 21 June 2019).

The construction of rain-fed reservoirs is one of the physical facilities built to be able to manage water irrigation to agriculture around Kulonprogo Regency. The construction of a reservoir to accommodate a lot of water during the rainy season is not a cheap program, therefore support from CSR of SOE and private companies is needed. Some farmer assistants provide traditional technology in the form of watering potted plants (bolapot) using banana weevil. Banana weevil is known as a tree that can produce high enough water or has a high water content. Therefore, the traditional technology of "banana weevil" is still applied in several districts.

"... On average, perennials are only in the stages of growth, rejuvenation and care. When the dry season and just the beginning of planting, we anticipate with holes, we punch holes in and given cotton so that later it will smear. That is to anticipate if the rain does not yet exist, if the roots are moist, it can last until the rainy season. At my place, if it's a drought season, just to wash my face, repent, mas, it's difficult. And for vegetables we can react with banana weevil, the way it is perforated because it contains a lot of water, is one of the breakthroughs "(Male, Kokap, June 20, 2019) 


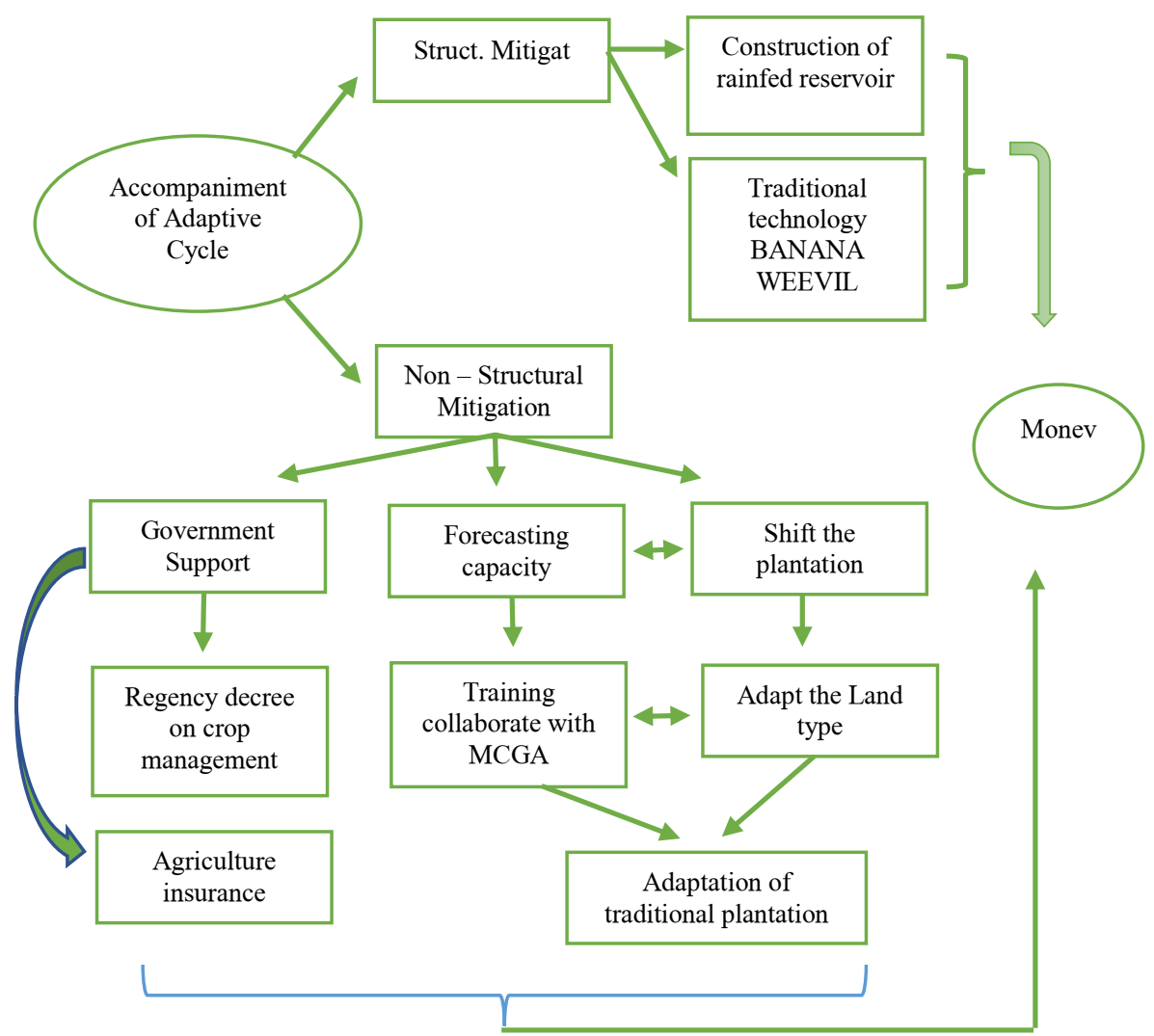

Fig. 3. Adaptive cycle of Farmers in Kulonprogo

Physical development programs, which are categorized as structural mitigation, require very high funding, so that not much development can be done in the adaptive capacity cycle for farmers. Non-structural mitigation programs are divided based on the type of independence and government support. Based on government support, the stipulation of a regent's regulation regarding planting arrangements can help reduce the risk of damage to agricultural land which results in a decrease in agricultural production. Including the agricultural insurance program, which has just been implemented for three years, is one form of government support as a non-structural mitigation in farmers' adaptive cycles in Kulonprogo.

A concrete example in Kulonprogo is that there is already a regulation regarding land use, the palawija rice is already set from what group, when the planting month is. Wates happened to be in Group 2, whose hopes in November had started planting but because of the low rainfall and irrigation, the planting was delayed back to December or January ... If in Wates during the rice season, yesterday there was a government program related to farm insurance. Farmers can also participate, only paying Rp. 35,000 per hectare has been subsidized by the government and has been socialized to farmers. Not just rice but livestock too" (Male, Wates, 20 June 2019)

Drastic climate change is a major challenge from farmers, which causes the value of agricultural sector production from year to year continues to decline. climate change impacts on climate change suddenly, so farmers need to be given the capacity to read climate change that is likely to occur as a preparation in determining the type of planting 
chosen. Therefore, in the non-structural mitigation category, increasing knowledge in the form of "titen" knowledge or reading weather forecasting, climate and also seasons that can suddenly change from year to year is very much needed. In collaboration with BMKG, farmers are given training in forecasting seasons, weather and climate to be able to determine the transfer of crop planting. This is one of the adaptive cycle activities carried out at the beginning of the dry season. The ability of farmers to identify and or forecast has been done for the last two years.

"... for the Kulonprogo area itself there are three main types of pests namely WBC (brown plant hopper) Rat and rice stem borer. We as a PUPT (pest monitoring) team collaborate with various parties, especially farmers to prevent them by monitoring them to use biological gens, which are usually applied on the 10th day after seeding, we also cooperate with the RPT (plant control team) of the government of the agriculture and food control district of Kulonprogo. When the rice plant enters the age of 30-40 days, the pests that often appear are rice stem pickers, fake and odd white pests. Then we control these pests by using biological agents or with corin, we are incessant in giving vigor to farmers to better optimize the use of biological agents than chemical pesticides. Because if they directly use chemical pesticides will have an impact on the absence of ecological engineering that will grow in the rice fields. WBC is one of the pests that is on the rise among Kulonprogo because its development is very fast". (Male, Kalibawang, 21 June 2019)

In addition, pest control is carried out by farmers by developing biological agents. This is the latest program carried out in almost all BPP assistants for farmers. From BPP Kalibawang explained in detail the four steps implemented with the development of biological agencies for pest control, namely:

1. By controlling plant technical culture such as healthy plant cultivation, spacing, selection of seed varieties and irrigation systems;

2. Using physical mechanical. For example in controlling rice stem borer pests, it can be seen from the beginning of the nursery such as a group of eggs at the top of the stem. If the companion is complacent and is not sensitive to the seedling of stem stems, it will be very detrimental and have an impact on crop yields. One of the ways we appeal to farmers is to eradicate the seeds, either directly killed on site manually or brought home and made into animal food such as fish or chicken. The point is that farmers do not want to damage the ecosystem of these pests, farmers only control the population in accordance with the ecosystem and the food chain, this is one of the ecological engineering efforts that we provide to farmers.

3. Using biological agents biological pesticides,

4. Using chemical pesticides. Provision of chemical pesticides is done at the end so that ecological engineering that is formed in the beginning (konco tani) can run well in accordance with its natural ecosystem.

\section{Conclusion and Recommendation}

This study determine the strategy of farmer for adapting the climate change. We interviewed the farmer assistants in Kulonprogo Yogyakarta, Indonesia, who were facing increased risks to pest attacks that result from climate change. The findings showed that the agricultural sector, based on the value of GRDP, dominates gross domestic output for input to other industries. This imply that infrastructure and physical growth are very important in 
the irrigation management system. Since Kulonprogo Regency has a different climate between districts, farmers' assistants try to reduce the risk of pests in different ways, one of which is adapting the types of plants from the environment in some areas. The adaptation capacity for farmers is gained through two kinds of items through a farmer companion, namely structural mitigation and non-structural mitigation. These methods should be implemented in a country such as Indonesia 's policies to deal with climate change. The results also suggest that approaches may be applicable in improving the National Action Plan on Adaptation to Climate Change (RAN-API) and the Indonesian Sectoral Roadmap on Climate Change (ICCSR), and in promoting new farming technologies among farmers. That said, future research is still needed to confirm farmers' adaptation strategies to help climate change adaptation in other Indonesian provinces as well as other countries as results may vary in different seasons or impacts of climate change in their agriculture sector.

Acknowledgement. The authors are grateful to Universitas Muhammadiyah Yogyakarta for funding this research with grant number 194/SK-LP3M/XII/2018.

\section{References}

1. Saptutyningsih, E., Diswandi, D., Jaung, W. Does social capital matter in climate change adaptation? A lesson from agricultural sector in Yogyakarta, Indonesia. Land Use Policy 95, 1-5. (2020).

2. Paul, C. J., Weinthal, E. S., Bellemare, M. F., \& Jeuland, M. A. Social capital, trust, and adaptation to climate change: Evidence from rural Ethiopia. Global Environmental Change, 36, 124-138. (2016). https://doi.org/10.1016/j.gloenvcha.2015.12.003

3. Asian Development Bank. The Economics of Climate Change in Southeast Asia: A Regional Review. Asian Development Bank. (2009).

4. Defiesta, G., \& Rapera, C. L. Measuring Adaptive Capacity of Farmers to Climate Change and Variability: Application of a Composite Index to an Agricultural Community in the Philippines. Journal of Environmental Science and Management, 17(2), 48-62. (2014).

5. O'neal, M. aaron o'neal. Late Little Ice Age glacier fluctuations in the Cascade Range of Washington and Northern Oregon. In University of Washington Phd (Issue January 2005). University of Washington. (2005).

6. Deressa, T. T., Hassan, R. M., Ringler, C., Alemu, T., \& Yesuf, M. Determinants of farmers' choice of adaptation methods to climate change in the Nile Basin of Ethiopia. Global Environmental Change, 19(2), 248-255. (2009). https://doi.org/10.1016/j.gloenvcha.2009.01.002

7. Di Falco, S., Bulte, E. Social Capital And Weather Shocks In Ethiopia: Climate Change And Culturally-Induced Poverty Traps. Csae Annual Conference. (2010).

8. Nyong, A. Technologies for adapting to climate change: water resources and agriculture. UNFCCC Seminar on the Development and Transfer of Environmentally Sound Technologies for Adaptation to Climate Change. (2005).

9. Dazé, A. Climate Change and Poverty in Ghana. CARE International. (2007).

10. Sorre, A. M., Kurgat, A., \& Sorre Bernard, R. M. Adaptive Capacity to Climate Change among Smallholder Farmers' in Busia County, Kenya. IOSR Journal of Agricultur and Veterinary Science (IOSR-JAVS), 10(11), 40-48. (2017). https://doi.org/10.9790/23801011014048

11. Hogan, A., Berry, H. L., Ng, P., \& Bode, A. Decisions Made by Farmers that Relate to 
Climate Change. Agricultural Science, 23, 36-39. (2011). http://www.rirdc.gov.au

12. Delaporte, I., \& Maurel, M. Adaptation to climate change in Bangladesh. Climate Policy, 18(1), 49-62. (2018). https://doi.org/10.1080/14693062.2016.1222261

13. Carter, M., Castillo, M. Trustworthiness and Social Capital In South Africa: An Experimental Approach. (2006).

14. Adger, W. N. Social and ecological resilience: Are they related? Progress in Human Geography, 24(3), 347-364. (2000). https://doi.org/10.1191/030913200701540465

15. Kassie, M., Pender, J., Yesuf, M., Kohlin, G., Bluffstone, R., \& Mulugeta, E. Estimating returns to soil conservation adoption in the northern Ethiopian highlands. Agricultural Economics, 38(2), 213-232. (2008). https://doi.org/10.1111/j.15740862.2008.00295.x

16. Bradshaw, B., Dolan, H., Smit, B. Farm-level adaptation to climatic variability and change: crop diversification in the Canadian Prairies. Climatic Change 67, 119-141. (2004).

17. Tashakkori, A., \& Teddlie, C. (2003a). Issues and dilemmas in teaching research methods courses in social and behavioral sciences: US perspective. International Journal of Social Research Methodology, 6(1), 61-77.

18. Patton MQ. 2002. Qualitative research and evaluation methods. London: Thousand Oaks, CA: Sage Publication.

19. Glaser, B.G., Strauss, A.L.The Discovery of Grounded Theory: Strategies for Qualitative Research. Aldine, Chicago. (1967)

20. Strauss, A., Corbin, J.: Basics of Qualitative Research: Techniques and Procedures for DevelopingGrounded Theory, 2nd edn. Sage, Thousand Oaks (13) (PDF) Saturation in qualitative research: exploring its conceptualization and operationalization. (1998). Available from: https://www.researchgate.net/publication /319752171_Saturation_in_qualitative_research_exploring_its_conceptualization_and_ operationalization [accessed June 03 2019].

21. Krueger R.A., Casey, M.A. Focus Groups: A Practical Guide for Applied Research, 3rd ed. Thousand Oaks, CA: Sage Publications. (2000).

22. Oktavia, R., Andjani, I.Y. Analisis Komoditas Unggulan Sektor Pertanian Kecamatan Samigaluh Kabupaten Kulonprogo, Yogyakarta. Jurnal Akuntansi, Ekonomi dan Manajemen Bisnis, 7(2). (2019). https://doi.org/10.30871/jaemb.v7i2.1598

23. Fauzana, H., Wagiman, F.X., Martono, E. Physiological disorders of brown planthopper associated with coal fly ash. Indonesian Journal of Entomology 11(1), 27-33. (2014).

24. Williams, C., Fenton, A., \& Huq, S. Knowledge and adaptive capacity. Nature Climate Change, 5(2), 82-83. (2015). https://doi.org/10.1038/nclimate2476

25. Eakin, H., Perales, H.R., Appendini, K., Sweeney, S. Selling maize in Mexico: the persistence of peasant farming in an era of global markets. Develop. Change 40, 133155. (2014). 